\title{
Early recolonization of a dredged lowland river by dragonflies (Insecta: Odonata)
}

\author{
Paweł Buczyński ${ }^{1, *}$, Andrzej Zawal ${ }^{2}$, Edyta Buczyńska ${ }^{3}$, Edyta Stępień ${ }^{4}$, Piotr Dąbkowski², \\ Grzegorz Michoński ${ }^{2}$, Agnieszka Szlauer-Łukaszewska², Joanna Pakulnicka ${ }^{5}$, \\ Robert Stryjecki ${ }^{3}$ and Stanisław Czachorowski ${ }^{5}$ \\ ${ }^{1}$ Department of Zoology, Maria Curie-Skłodowska University, Akademicka 19, 20-033 Lublin, Poland \\ 2 Department of Invertebrate Zoology and Limnology, University of Szczecin, Waska 13, 71-415 Szczecin, Poland \\ ${ }^{3}$ Department of Zoology, Animal Ecology and Wildlife Management, University of Life Sciences in Lublin, Akademicka 13, 20-033 \\ Lublin, Poland \\ ${ }^{4}$ Department of Plant Taxonomy and Phytogeography, University of Szczecin, Waska 13, 71-415 Szczecin, Poland \\ ${ }^{5}$ Department of Ecology and Environmental Protection, University of Warmia and Mazury in Olsztyn, Plac Łódzki 3, \\ 10-727 Olsztyn, Poland
}

\begin{abstract}
The influence of dredging on the dragonfly assemblages of the small regulated lowland River Krąiel (north-western Poland) was analyzed a short time after the dredging. Dragonfly assemblages were destroyed, but they began to recover rapidly. Many biocoenotic indices reached high values at just six months after the dredging. The recolonization first occurred as a result of larval drift, and then, via dispersion of adult dragonflies. This process took place in conditions different from the prevailing conditions in the period before dredging, in terms of microhabitat availability and physico-chemical conditions. Compared to the previous assemblage, the emerging assemblage was more typical of assemblages found in small, natural running waters. Therefore, dredging (carried out for economic reasons) could be regarded as a process that unintentionally had a positive influence on odonate assemblages. Currently, when most small watercourses are regulated, dredging that is properly planned and controlled has proven to protect the natural fauna. It is worthwhile to apply lessons learned from examples of active fauna protection to what is currently known as "the rotational model" for dredging.
\end{abstract}

Keywords: Odonata / river / dredging / alteration / recolonization

Résumé - Recolonisation précoce par des libellules (Insecte : Odonate) d'une rivière de plaine draguée. L'influence du dragage sur les assemblages de libellules de la petite rivière régulée Krąpiel (nordouest de la Pologne) a été analysée peu de temps après le dragage. Les assemblages de libellules ont été détruits, mais ils ont commencé à se rétablir rapidement. De nombreux indices biocénotiques ont atteint des valeurs élevées seulement six mois après le dragage. La recolonisation a d'abord été le résultat de la dérive larvaire, puis celui de la dispersion des libellules adultes. Ce processus s'est déroulé dans des conditions différentes des conditions prévalant dans la période précédant le dragage, en termes de disponibilité de microhabitats et de conditions physico-chimiques. Par rapport à l'assemblage précédent, l'assemblage émergeant était plus typique des assemblages trouvés dans de petites eaux courantes naturelles. Par conséquent, le dragage (effectué pour des raisons économiques) pourrait être considéré comme un processus qui a involontairement eu une influence positive sur les assemblages d'odonates. À l'heure actuelle, lorsque la plupart des petits cours d'eau sont régulés, le dragage convenablement planifié et contrôlé a prouvé qu'il protégeait la faune naturelle. Il serait bon d'appliquer les leçons tirées des exemples de protection active de la faune à ce qu'on appelle actuellement le « modèle de rotation » pour le dragage.

Mots-clés : Odonate / rivière / dragage / altération / recolonisation

\footnotetext{
* Corresponding author: pawbucz@gmail.com
} 


\section{Introduction}

The anthropogenic transformation of rivers and river valleys is a common phenomenon that severely alters the ecosystems of these areas (Naiman et al., 1995; Ward et al., 1999; Rosenberg et al., 2000; Carpenter et al., 2011). The consequences of these changes, and possibilities for mitigating or reversing the changes, have received great attention (Kiene, 1996; Kamada et al., 2004; Lüderitz et al., 2004; Svendsen et al., 2009). These consequences are nearly always assessed as negative. However, in some situations, regulation has had no negative effect on the state of the ecosystem, or at least elements of it (e.g., Holčík and Macura, 2001). Moreover, in $13.8 \%$ of cases, ecological indicators have improved after regulative measures were imposed (Poff and Zimmerman, 2010). This finding indicates the importance of appropriate planning for hydrotechnical procedures; appropriate planning can significantly reduce ecological damage. Thus, despite the fairly rich literature on the subject, the consequences of river transformations remain a research subject of great importance.

Dredging is one procedure that has a particularly strong effect on river biocoenoses. Dredging affects many key features of the environment, including water flow velocity, the composition and structure of bottom sediments, availability of light, and the quantity and spatial structure of vegetation. It also directly affects organisms, by removing them from the environment along with sediments and vegetation (Aldridge, 2000). During hydrotechnical procedures, organisms are also threatened by an increase in the abundance of suspended matter and by the negative effects of resuspended bottom sediments (de Jonge and de Jong, 2002; Phelps, 2001). However, one may also postulate that dredging a river that has previously undergone regulation might be favourable for the biocoenoses, particularly in a lowland watercourse with a slow current. In those conditions, dredging might reverse succession, eliminate the effects of mud accumulation and overgrowth, and restore optimal microhabitats for rheobionts and rheophiles. The aim of this study was to verify this hypothesis by analyzing dragonfly assemblages. Dragonflies were selected as a research model for two main reasons. First, they are significant elements in the fauna of running waters and adjoining valleys, in terms of their frequency of appearance, abundance, and role in the ecosystems (Czachorowski et al., 1993; Ward et al., 1999; Benke et al., 2001; Chovanec and Waringer, 2001; Motta and Uieda, 2004; Poff et al., 2006; Koprowska and Jabłońska-Barna, 2007). Second, they are regarded as good indicators of the state of the ecosystem and overall biodiversity. Therefore, conclusions drawn from research on dragonflies can be applied to other taxonomic groups, and even entire ecosystems (Bulánková, 1997; Sahlén and Ekestubbe, 2001; Chovanec and Waringer, 2001; Chovanec et al., 2004; Gerlach et al., 2013; da Silva Monteiro Júnior et al., 2015).

\section{Materials and methods}

\subsection{Study area}

The study area was in the West Pomeranian Lakeland in north-western Poland (Kondracki, 2000), about $35 \mathrm{~km}$ to the west of Szczecin, near the village of Dzwonowo. The analysis was performed on a $3-\mathrm{km}$ stretch of the middle course of the

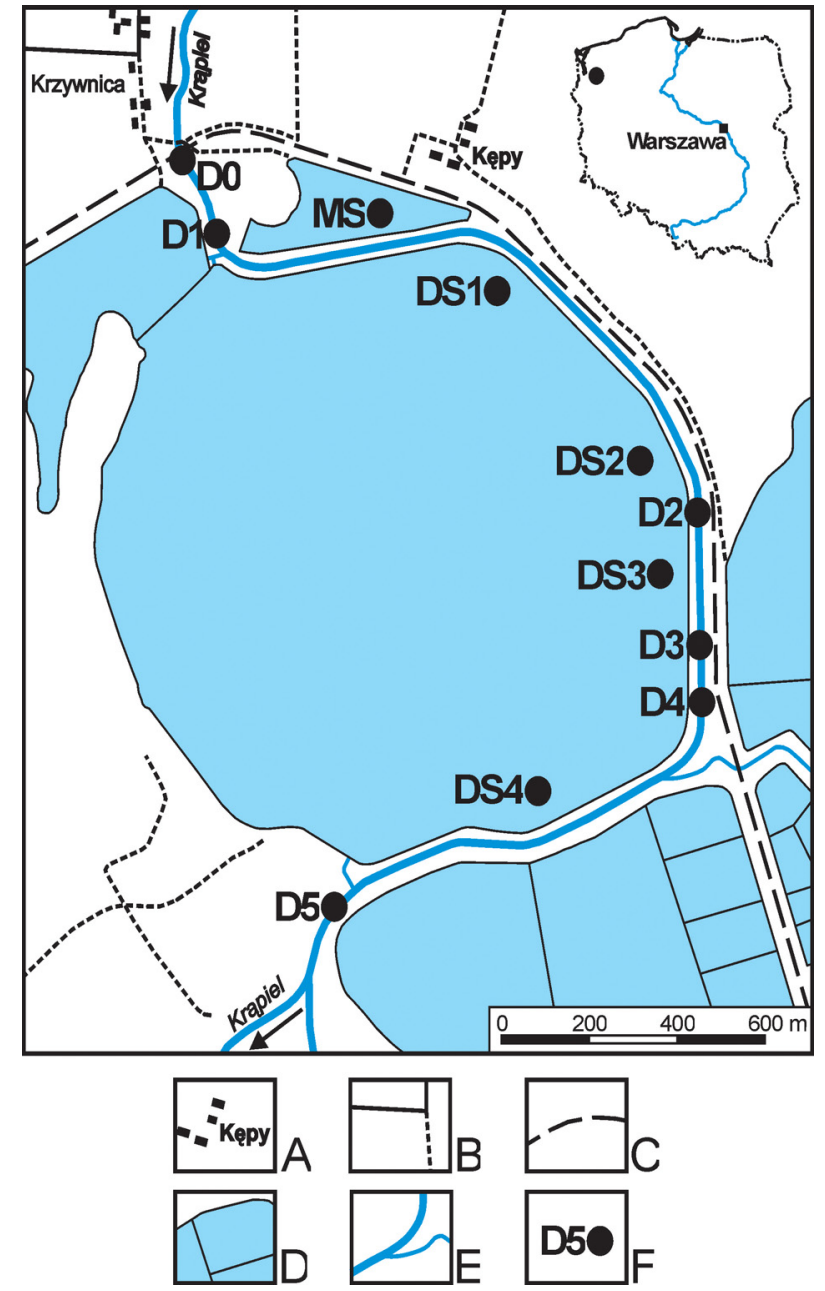

Fig. 1. Study area and sampling sites. Key: A - buildings, B - roads, $\mathrm{C}$ - railway, $\mathrm{D}$ - fish ponds, $\mathrm{E}$ - running waters, $\mathrm{F}$ - sampling sites.

River Krapiel, from the dam in the village of Kępy to the stretch below the fish pond complex $\left(53^{\circ} 25^{\prime} 22^{\prime \prime}-53^{\circ} 24^{\prime} 32^{\prime \prime} \mathrm{N}\right.$, $15^{\circ} 11^{\prime} 36^{\prime \prime}-15^{\circ} 11^{\prime} 58^{\prime \prime} \mathrm{E}$ ) (Fig. 1). A map on the website, geoportal.gov.pl, probably from 1973, showed that the present river channel is $95 \%$ artificial in this area. Previously, the Krapiel flowed in a straight, regulated channel, between sampling site D1 and a location about $100 \mathrm{~m}$ upstream of site D5, through meadows intersected by drainage ditches. Currently, there is a fish pond between D1 and D5, which harbours sites DS1-DS4 (Fig. 1). This geography has been constant, at least since the interwar period - it was shown on a German Messtischblatt map from 1931 (no. 2557 Schönebeck).

Before dredging, the examined stretch of the Krapiel was a slow-flowing canal, shaded by willows and alders growing on the banks. It was up to 1-m deep, and its bottom was muddy, in some places overgrown with Phragmites australis arrowhead or Elodea canadensis. Its banks were relatively steep, with alluvial deposits, and covered mainly with a Phalaridetum arundinaceae association. At the level of the fish ponds, the river became wider, with flood plains about 5-m wide, covered mainly with Phalaridetum arundinaceae and Phragmitetum australis. In the river bed, the largest areas were covered with a Sagittario-Sparganietum emersi association, together with arrowhead and Sparganium emersum. Oenantho-Rorippetum 
Table 1. Characteristics of sampling sites before and after dredging.

\begin{tabular}{|c|c|c|c|c|c|c|c|c|c|c|}
\hline \multirow[t]{3}{*}{ Site } & \multicolumn{10}{|c|}{ Parameters } \\
\hline & \multicolumn{2}{|c|}{ Flow $\left[\mathrm{m} \mathrm{s}^{-1}\right]$} & \multicolumn{2}{|c|}{ Depth $[\mathrm{m}]$} & \multicolumn{2}{|c|}{ Bottom sediments } & \multicolumn{2}{|c|}{ Plants [\%] } & \multicolumn{2}{|c|}{ Shade } \\
\hline & Before & After & Before & After & Before & After & Before & After & Before & After \\
\hline $\mathrm{D} 0 / 1^{*}$ & 0.500 & $0.460-0.510$ & 0.7 & 0.7 & $\mathrm{~g}$, st & $\mathrm{g}, \mathrm{st}$ & 0 & 0 & None & None \\
\hline $\mathrm{D} 0 / 2^{*}$ & 0.010 & $0.002-0.020$ & 0.5 & 0.5 & sa, si, m & $\mathrm{sa}, \mathrm{si}, \mathrm{m}$ & 70 & $50-70$ & Partial & Partial \\
\hline D1/1 & 0.013 & $0.090-0.160$ & 0.4 & 0.5 & $\mathrm{~m}$ & $\mathrm{sa}, \mathrm{g}$ & 30 & $0-10$ & None & None \\
\hline $\mathrm{D} 1 / 2$ & 0.010 & $0.002-0.010$ & 0.2 & 0.2 & si, m & $\mathrm{sa}, \mathrm{si}, \mathrm{m}$ & 90 & $0-40$ & Partial & None \\
\hline $\mathrm{D} 2 / 1$ & 0.020 & $0.010-0.050$ & 0.2 & 0.5 & si, m & si, m & 90 & $0-10$ & Partial & None \\
\hline $\mathrm{D} 2 / 2$ & 0.002 & $0.001-0.002$ & 0.1 & 0.2 & $\mathrm{~m}$ & $\mathrm{~m}$ & 100 & $0-40$ & Partial & None \\
\hline $\mathrm{D} 3 / 1$ & 0.020 & $0.020-0.050$ & 0.3 & 0.5 & si, m & $\mathrm{sa}, \mathrm{si}, \mathrm{m}$ & 20 & $0-10$ & Partial & None \\
\hline $\mathrm{D} 3 / 2$ & 0.002 & $0.001-0.002$ & 0.1 & 0.2 & $\mathrm{~m}$ & $\mathrm{sa}, \mathrm{si}, \mathrm{m}$ & 80 & $0-40$ & Partial & Partial \\
\hline $\mathrm{D} 4 / 1^{*}$ & 0.140 & $0.090-0.200$ & 0.5 & 0.5 & $\mathrm{sa}, \mathrm{g}$ & $\mathrm{sa}, \mathrm{g}$ & 0 & 0 & Partial & Partial \\
\hline $\mathrm{D} 4 / 2^{*}$ & 0.003 & $0.001-0.003$ & 0.2 & 0.2 & $\mathrm{sa}, \mathrm{m}$ & $\mathrm{sa}, \mathrm{m}$ & 70 & $30-70$ & Partial & Partial \\
\hline D5/1 & 0.001 & $0.001-0.003$ & 0.5 & 0.7 & $\mathrm{~m}$ & $\mathrm{~m}$ & 40 & $0-40$ & Partial & None \\
\hline $\mathrm{D} 5 / 2$ & 0.040 & $0.030-0.060$ & 0.5 & 1.0 & $\mathrm{~m}$ & $\mathrm{~m}$ & 30 & $0-20$ & None & None \\
\hline
\end{tabular}

* Control sites (undredged); river bottom sediments: $\mathrm{g}$ - gravel, st - stones, sa - sand, si - silt, $\mathrm{m}$ - mud.

and Elodeetum canadensis were also present, and some sites included a Nupharo-Nymphaeetum albae association, composed of yellow water lily. Phragmites australis had invaded many locations over the river bed. In two sites, the river was relatively shallow (about $0.5-\mathrm{m}$ deep), and the flow was rapid. The bottom consisted of either rocks and gravel or gravel and sand, and it was partially overgrown with Fontinalis antipyretica, which together with Callitriche sp., Sparganium emersum fo. fluitans, and Nuphar lutea fo. submersa formed a rudimentarily developed Fontinalis antipyretica community.

Dredging was conducted in late January and early February 2009. It involved restoring the regulated stretch of the river to its previous appearance by removing plants and accumulated silt deposits and by falling some trees and shrubs growing on the river banks. The width of the river remained unchanged. All reed beds and macrophyte vegetation were removed, except in the control stretches, located before the weir (sites D0/1 and D0/2) and under the bridge (sites D4/1 and D4/2), which had remained intact. A 5-m wide band of reed beds and willow shrubbery were removed from both sides of the river, leaving only isolated trees (alders and willows). The removal of sediment did not modify the natural stream slope; therefore, pools with stagnant water did not appear. About $80 \%$ of the mud that had filled the river bed was removed, in addition to loam and sand, which had accumulated in some locations. Channel patency increased by $20-50 \%$ in places that had not been covered with reed beds, and by $80 \%$ in places that had been covered with reed beds. Six research sites were selected along the targeted stretch of the river (D0-D5). At each site, two sub-sites were established (e.g., D0/1, D0/2), one in the river current and one in the marginal zone. The changes observed at each research site are given in Table 1.

\subsection{Field research}

Field research was carried out before dredging, in July 2008, and after dredging, from April to August 2009 (14.09.2009, 12.05.2009, 14.06.2009, 15.07.2009, and 12.08.2009). Samples were collected from all sites. The research conducted after dredging covered a full growing season. The study included four dredged sites (D1, D3, D3, and D5) and two undredged sites (D0 and D4) as controls. To determine the extent of refuge provided by the fish ponds for the fauna inhabiting the river after dredging, sampling was conducted in July 2009 at five sites: DS1-DS4 (in a large pond), and MS (in a small pond) (Fig. 1). Unfortunately, for reasons beyond the control of the authors, pre-dredging samples were only collected once, and post-dredging samples were collected at monthly intervals.

Adult dragonflies were collected with an entomological net. All imagos were caught from the water surface, in an area about $10 \mathrm{~m}^{2}$ on each side of the bank. Larvae were collected in two different environments, in running current and in pool environments. Larva samples were collected with a hydrobiological sampler, with a triangular hoop: having side length $30 \mathrm{~cm}$ and mesh size $20 \mu \mathrm{m}$. The sampling method involved 20 sweeps, which were performed directly above the river bottom surface, over an area of about $1-\mathrm{m}^{2}$ for each sample. Among the adult dragonflies, we collected 42 samples above the river surface, including 6 samples before and 36 samples after dredging, and 5 samples above the surfaces of fish ponds. Among the dragonfly larvae, we collected 72 samples in the river, 12 samples before and 60 samples after dredging, and 5 samples in the fish ponds.

Water current velocity was measured with a FlowTracker Acoustic Doppler Velocimeter. To assess the effect of dredging on the environment, we applied a negative time scale, with the time lapse calculated from dredging to sampling, i.e., April - 5, August - 0. Vegetation cover was estimated visually with the phytosociological method developed by Braun-Blanquet (1964). A four-grade scale was used to assess the degree of bottom coverage with macrophyte vegetation, where 0 indicated the absence of plants and 3 indicated total coverage. Bottom sediment components (sand, silt, and detritus) were assessed by allocating a numerical value to each component; the sum of these values always equalled 3 , 
and the points allotted to respective components reflected their proportions in the sediment volume.

\subsection{Data analysis}

The material was identified by the first author and it was deposited in the collections of the Department of Zoology of Maria Curie-Skłodowska University in Lublin, Poland.

Dominance (D) and frequency (F) indices were used to evaluate species. Species composition was determined based on the following five groups: eudominants $(>10.0 \%)$, dominants $(5.01-10.0 \%)$, sub-dominants $(1.01-5.00 \%)$, recedents $(0.50-1.00 \%)$, and sub-recedents $(<0.50 \%)$. Species diversity was defined according to the Shannon-Wiener $(\mathrm{H})$ and Hurlbert (PIE) indices (Lampert and Sommer, 1997). The relationships between dragonfly assemblages and environmental parameters were determined on the basis of Spearman's rank correlation coefficients.

The distribution of data was tested with the Shapiro-Wilk test. Statistical significance of differences between groups was tested with the Mann-Whitney test (for two independent samples) and the Kruskal-Wallis test (for more than two independent samples).

Our study design required data on the following two sites: a control site and an impact site; thus, we analysed two types of comparison: (1) BA - before and after and (2) CI - control and impact sites. We analysed 24 samples collected in July: 12 "before" and 12 "after" (4 from the control and 8 from the impact sites). To analyse the interaction between these two types of comparison, we implemented the BACI test, which estimates the BA $\times$ CI interaction (Smith et al., 1993). This interaction was tested in two ways: (1) with the Odonata abundance test, where each species was recorded and expressed as the number of individuals at a given site and (2) with the Shannon-Wiener Index, where the biodiversity of Odonata was counted and recorded for each site. The abundance of Odonata was used as the dependent variable. BACI was tested with a generalized mixed model (GLMM) with a log link and a negative binomial distribution. This approach is suitable when dependent variables show high variation. We treated the species as a random effect (intercept) with a scaled identity covariance. The species diversity of each site was computed with the Shannon-Wiener Index, and it was treated as a dependent variable. BACI was tested with a factorial ANOVA.

We used the multivariate ordination method known as a Detrended Correspondence Analysis (DCA; Hill and Gauch, 1980; ter Braak and Prentice, 1988) to assess the range of the environmental gradient. Once we verified, with the DCA, that the environmental gradient covered was sufficiently long, we implemented a CCA (ter Braak, 1986; ter Braak and Verdonschot, 1995) to assess the community ordination of dragonfly assemblages relative to environmental variables.

We used the habitat preferences of odonate species described by Bernard et al. (2009).

\section{Results}

A total of 593 individuals (428 adults and 165 larvae) were collected, representing 28 dragonfly species. Before the dredging, 282 imagos (18 species) and 33 larvae (7 species) were recorded; after the dredging, 130 imagos (17 species) and 40 larvae (10 species) were recorded. At the fish ponds, 16 imagos (7 species) and 92 larvae (6 species) were collected (Tabs. 2 and 3). The differences in the number of species between these collections were statistically insignificant (imagos: $H(2, N=22)=0.110, \quad p=0.946$; larvae: $H(2$, $N=29)=3.719, p=0.155)$. The differences in abundances of imagos were also insignificant $(H(2, N=22)=0.327$, $p=0.849)$, but the differences in abundances of larvae were significant $(H(2, N=29)=7.156, p=0.027)$, including larvae present in the river before and after the dredging $(Z=2.587$, $p=0.009)$. The differences in the numbers of specimens of the most numerous species in the river (Calopteryx splendens, Platzcnemis pennipes and Ischnura elegans) were not statistically significant: $Z=0.958, \quad p=0.337 ; \quad Z=0.000$, $p=1.000 ; Z=0.557, p=0.577$, respectively.

The species diversity indices for imagos in the river before the dredging, in the river after the dredging, and in the fish ponds were as follows: $H=2.262$, $\mathrm{PIE}=0.858 ; H=0.796$, $\mathrm{PIE}=0.393$; and $H=1.787$, PIE $=0.765$, respectively. These values were not significantly different (for the Shannon-Wiener Index: $H(2, N=13)=1.875, p=0.391$; and for PIE: $H$ $(2, N=13)=1.760, p=0.414)$. The species diversity indices for larvae were $H=1.699, \mathrm{PIE}=0.758$ in the river before dredging; $H=1.998, \mathrm{PIE}=0.815$ in the river after dredging; and $H=0.654, \mathrm{PIE}=0.273$ in the fish ponds. Again, these values were not significantly different (for the Shannon -Wiener Index: $H(2, N=22)=3.508, p=0.173$; and for PIE: $H$ $(2, N=22)=3.933, p=0.1399)$.

Among the collected larvae, the most abundant species were Sympetrum depressiusculum, Ischnura elegans, Calopteryx splendens, and C. virgo. Apart from Sympetrum depressiusculum, these were also the most frequently collected species. The dominance structure in the river was similar before and after the dredging. The most abundant species before the dredging were Ischnura elegans, Calopteryx splendens, Gomphus vulgatissimus, and Calopteryx virgo; the most numerous after the dredging were Calopteryx virgo, Ischnura elegans, Gomphus vulgatissimus, Calopteryx splendens, and Platycnemis pennipes. One eudominant, Sympetrum depressiusculum, was noted in the fish ponds, and it had a very high dominance index (Tab. 2).

Among the imagos, the most abundant and most frequently collected species were Coenagrion puella, Ischnura elegans, Lestes sponsa, Calopteryx virgo, and Platycnemis pennipes. The similar dominance structure was found in the Krapiel before the dredging, except the positions of Calopteryx virgo and Platycnemis pennipes were different. This dominance structure changed after the dredging, when the most abundant and most frequently caught species were Sympetrum sanguineum, Coenagrion puella, Sympetrum depressiusculum, Ischnura elegans, Lestes sponsa, and Calopteryx virgo. The dominant species at the fish ponds were Ischnura elegans, Sympecma fusca, Lestes dryas, and Sympecma paedisca (Tab. 3).

Assemblages of dragonfly larvae in the fish ponds and the river were very different; only Aeshna mixta and Sympetrum vulgatum were caught in both habitats. In the river, dredging only slightly altered the species composition; all the species caught before dredging remained after dredging, and in addition, two previously unrecorded species were present after 
P. Buczyński et al. : Knowl. Manag. Aquat. Ecosyst. 2016, 417, 43

Table 2. Species of dragonfly larvae collected. $N$ - number of specimens, $D-$ dominance [\%], $F-$ frequency [\%].

\begin{tabular}{|c|c|c|c|c|c|c|c|c|c|c|c|c|}
\hline \multirow[t]{2}{*}{ Species } & \multicolumn{3}{|c|}{ Total } & \multicolumn{3}{|c|}{ Before dredging } & \multicolumn{3}{|c|}{ After dredging } & \multicolumn{3}{|c|}{ Fish ponds } \\
\hline & $N$ & $D$ & $F$ & $N$ & $D$ & $F$ & $N$ & $D$ & $F$ & $N$ & $D$ & $F$ \\
\hline Calopteryx splendens (Harris) & 14 & 8.5 & 0.4 & 9 & 27.3 & 0.6 & 5 & 12.5 & 0.4 & - & - & - \\
\hline C. virgo (Linnaeus) & 14 & 8.5 & 0.4 & 3 & 9.1 & 0.2 & 11 & 27.5 & 0.4 & - & - & - \\
\hline Lestes sponsa (Hansemann) & 2 & 1.2 & 0.1 & - & - & - & - & - & - & 2 & 2.2 & 0.3 \\
\hline Sympecma paedisca (Brauer) & 5 & 3.0 & 0.2 & - & - & - & - & - & - & 5 & 5.4 & 0.7 \\
\hline Platycnemis pennipes (Pallas) & 7 & 4.2 & 0.2 & 3 & 9.1 & 0.2 & 4 & 10 & 0.3 & - & - & - \\
\hline Ischnura elegans (Vander Linden) & 19 & 11.5 & 0.4 & 11 & 33.3 & 0.6 & 8 & 20 & 0.4 & - & - & - \\
\hline Erythromma najas (Hansemann) & 2 & 1.2 & 0.1 & 1 & 3.0 & 0.1 & 1 & 2.5 & 0.1 & - & - & - \\
\hline Aeshna cyanea (O.F. Müller) & 1 & 0.6 & 0.1 & - & - & - & 1 & 2.5 & 0.1 & - & - & - \\
\hline A. mixta (Latreille) & 5 & 3.0 & 0.2 & - & - & - & 2 & 5 & 0.1 & 3 & 3.3 & 0.7 \\
\hline Gomphus vulgatissimus (Linnaeus) & 10 & 6.1 & 0.2 & 4 & 12.1 & 0.3 & 6 & 15 & 0.3 & - & - & - \\
\hline Somatochlora metallica (Vander Linden) & 1 & 0.6 & 0.1 & - & - & - & 1 & 2.5 & 0.1 & - & - & - \\
\hline Sympetrum depressiusculum (Selys) & 78 & 47.3 & 0.1 & - & - & - & - & - & - & 78 & 84.8 & 0.3 \\
\hline S. sanguineum (O.F. Müller) & 1 & 0.6 & 0.1 & - & - & - & - & - & - & 1 & 1.1 & 0.3 \\
\hline S. vulgatum (Linnaeus) & 6 & 3.6 & 0.2 & 2 & 6.1 & 0.2 & 1 & 2.5 & 0.1 & 3 & 3.3 & 0.3 \\
\hline Total & & 165 & & & 33 & & & 40 & & & 92 & \\
\hline
\end{tabular}

Table 3. Species of adult dragonflies collected. $N$ - number of specimens, $D$ - dominance [\%], $F-$ frequency [\%].

\begin{tabular}{|c|c|c|c|c|c|c|c|c|c|c|c|c|}
\hline \multirow[t]{2}{*}{ Species } & \multicolumn{3}{|c|}{ Total } & \multicolumn{3}{|c|}{ Before dredging } & \multicolumn{3}{|c|}{ After dredging } & \multicolumn{3}{|c|}{ Fish ponds } \\
\hline & $N$ & $D$ & $F$ & $N$ & $D$ & $F$ & $N$ & $D$ & $F$ & $N$ & $D$ & $F$ \\
\hline Calopteryx splendens (Harris) & 22 & 5.1 & 0.5 & 17 & 6.0 & 1 & 5 & 3.8 & 0.1 & - & - & - \\
\hline C. virgo (Linnaeus) & 37 & 8.6 & 0.6 & 24 & 8.5 & 0.8 & 13 & 10.0 & 0.7 & - & - & - \\
\hline Lestes dryas (Kirby) & 3 & 0.7 & 0.1 & - & - & - & - & - & - & 3 & 18.8 & 0.5 \\
\hline L. sponsa (Hansemann) & 50 & 11.7 & 0.4 & 36 & 12.8 & 0.6 & 14 & 10.8 & 0.4 & - & - & - \\
\hline Sympecma fusca (Vander Linden) & 6 & 1.4 & 0.4 & 2 & 0.7 & 0.4 & & & & 4 & 25.0 & 0.5 \\
\hline S. paedisca (Brauer) & 14 & 3.3 & 0.4 & 11 & 3.9 & 0.6 & 1 & 0.8 & 0.1 & 2 & 12.5 & 0.5 \\
\hline Platycnemis pennipes (Pallas) & 31 & 7.2 & 0.5 & 25 & 8.9 & 0.8 & 6 & 4.6 & 0.4 & - & - & - \\
\hline Ischnura elegans (Vander Linden) & 80 & 18.7 & 0.6 & 62 & 22.0 & 0.8 & 14 & 10.8 & 0.6 & 4 & 25.0 & 0.5 \\
\hline I. pumilio (Charpentier) & 1 & 0.2 & 0.1 & - & - & - & - & - & - & 1 & 6.3 & 0.5 \\
\hline Pyrrhosoma nymphula (Sulzer) & 1 & 0.2 & 0.1 & - & - & - & 1 & 0.8 & 0.1 & - & - & - \\
\hline Coenagrion puella (Linnaeus) & 81 & 18.9 & 0.6 & 63 & 22.3 & 0.8 & 18 & 13.8 & 0.7 & - & - & - \\
\hline C. pulchellum (Vander Linden) & 2 & 0.5 & 0.2 & 2 & 0.7 & 0.4 & - & - & - & - & - & - \\
\hline Enallagma cyathigerum (Charpentier) & 5 & 1.2 & 0.2 & 5 & 1.8 & 0.4 & - & - & - & - & - & - \\
\hline Erythromma najas (Hansemann) & 1 & 0.2 & 0.1 & 1 & 0.4 & 0.2 & - & - & - & - & - & - \\
\hline E. viridulum (Charpentier) & 1 & 0.2 & 0.1 & - & - & - & - & - & - & 1 & 6.3 & 0.5 \\
\hline Gomphus vulgatissimus (Linnaeus) & 3 & 0.7 & 0.3 & 1 & 0.4 & 0.2 & 1 & 0.8 & 0.1 & 1 & 6.3 & 0.5 \\
\hline Somatochlora metallica (Vander Linden) & 8 & 1.9 & 0.1 & 4 & 1.4 & 0.2 & 4 & 3.1 & 0.1 & - & - & - \\
\hline S. flavomaculata (Vander Linden) & 1 & 0.2 & 0.1 & - & - & - & 1 & 0.8 & 0.1 & - & - & - \\
\hline Orthetrum cancellatum (Linnaeus) & 11 & 2.6 & 0.3 & 11 & 3.9 & 0.6 & - & - & - & - & - & - \\
\hline Crocothemis erythraea (Brullé) & 1 & 0.2 & 0.1 & 1 & 0.4 & 0.2 & - & - & - & - & - & - \\
\hline Sympetrum danae (Sulzer) & 1 & 0.2 & 0.1 & - & - & - & 1 & 0.8 & 0.1 & - & - & - \\
\hline S. depressiusculum (Selys) & 17 & 4.0 & 0.3 & - & - & - & 17 & 13.1 & 0.4 & - & - & - \\
\hline S. flaveolum (Linnaeus) & 2 & 0.5 & 0.1 & 1 & 0.4 & 0.2 & 1 & 0.8 & 0.1 & - & - & - \\
\hline S. meridionale (Selys) & 2 & 0.5 & 0.2 & - & - & - & 2 & 1.5 & 0.3 & - & - & - \\
\hline S. sanguineum (O.F. Müller) & 31 & 7.2 & 0.5 & 8 & 2.8 & 0.4 & 23 & 17.7 & 0.7 & - & - & - \\
\hline S. vulgatum (Linnaeus) & 16 & 3.7 & 0.4 & 8 & 2.8 & 0.6 & 8 & 6.2 & 0.3 & - & - & - \\
\hline Total & & 428 & & & 282 & & & 130 & & & 16 & \\
\hline
\end{tabular}




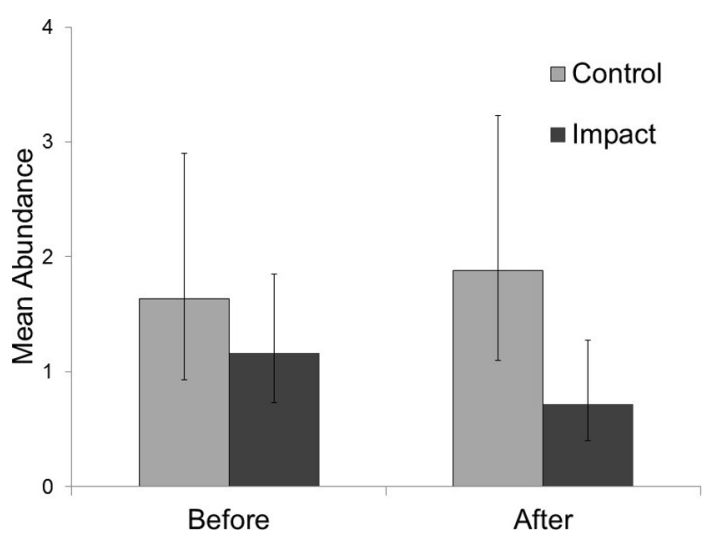

Fig. 2. Mean changes in the abundance of Odonata, based on the BACI analysis. Symbols show mean values and confidence intervals. The interaction is not significant $(p=0.25)$.

Table 4. Generalized mixed model results show the effects of dredging.

\begin{tabular}{lllll}
\hline Source & $F$ statistics & df1 & df2 & Significance \\
\hline Corrected Model & 2.357 & 3 & 50 & 0.083 \\
Before-after & 0.415 & 1 & 50 & 0.522 \\
Control-impact & 5.951 & 1 & 50 & 0.018 \\
BA $\times$ CI & 1.355 & 1 & 50 & 0.250 \\
\hline
\end{tabular}

dredging (Aeshna mixta and Somatochlora metallica). However, certain elements of the dominance structure changed. There were significant decreases in the proportions of Calopteryx splendens and Ischnura elegans, and there was also some decrease in the proportion of Sympetrum vulgatum. We noted a substantial increase in the relative abundance of Calopteryx virgo and a smaller, but distinct, increase in Gomphus vulgatissimus (Tab. 2).

The BACI interaction showed that, after the impact, the abundance of Odonata decreased, but not significantly (Fig. 2, Tab. 4). The levels of Odonata diversity were similar before and after the dredging, and the differences were not significant (Fig. 3, Tab. 5).

Prior to dredging, larvae of four rheophilic and rheobiontic species were noted in the Krapiel, and these accounted for $57 \%$ of all species. The remainder of the assemblage comprised stagnophilic, eurytopic dragonflies. After the dredging, the qualitative composition of the group of rheophilic and rheobiontic species was unchanged, but the number of stagnophilic species increased; thus, the qualitative proportion of stenotopic species associated with running waters in the assemblage fell to $44 \%$ (Tab. 2). In the river, the number and abundances of species observed before dredging were not significantly different from those observed after dredging, in either of the synecological groups (stagnophiles, number of species: $Z=0.848, p=0.629$; stagnophiles, number of individuals: $Z=1.114, p=0.264$; rheophiles, number of species: $Z=10.685, p=0.493$; rheophiles, number of individuals: $Z=1.227, p=0.219$ ).

In the river, after dredging, the number and abundance of species observed as larvae were low in the spring months, fell to zero in June, and increased markedly in August (Fig. 4). In

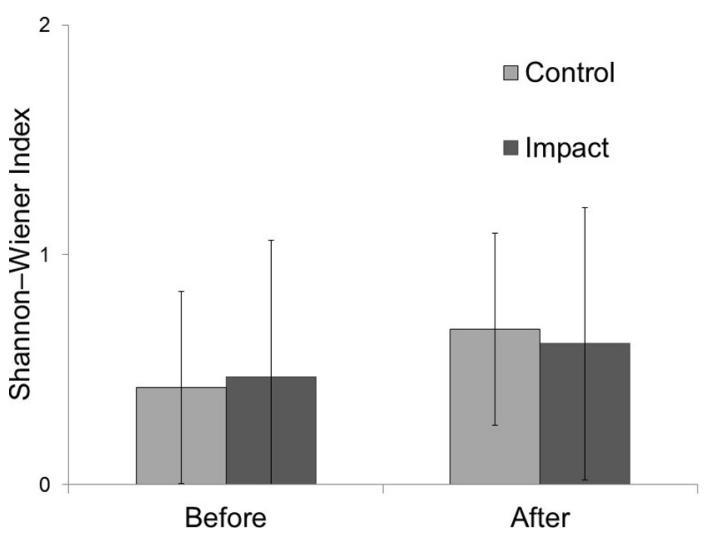

Fig. 3. Shannon-Wiener Index shows changes in Odonata diversity. Symbols show mean values and confidence intervals. The interaction was not significant $(p>0.05)$.

Table 5. Factorial ANOVA results show the effects of dredging.

\begin{tabular}{lrrrrl}
\hline Source & $\begin{array}{l}\text { Sum of } \\
\text { squares }\end{array}$ & Df & $\begin{array}{l}\text { Mean } \\
\text { square }\end{array}$ & $F$-statistic & $p$ \\
\hline Intercept & 31.697 & 1 & 31.697 & 130.938 & 0.000 \\
Before-after & 3.233 & 1 & 3.233 & 13.355 & 0.002 \\
Control-impact & 2.665 & 1 & 2.665 & 11.008 & 0.003 \\
BA $\times$ CI & 0.097 & 1 & 0.097 & 0.403 & 0.533 \\
Error & 4.841 & 20 & 4.841 & & \\
\hline
\end{tabular}

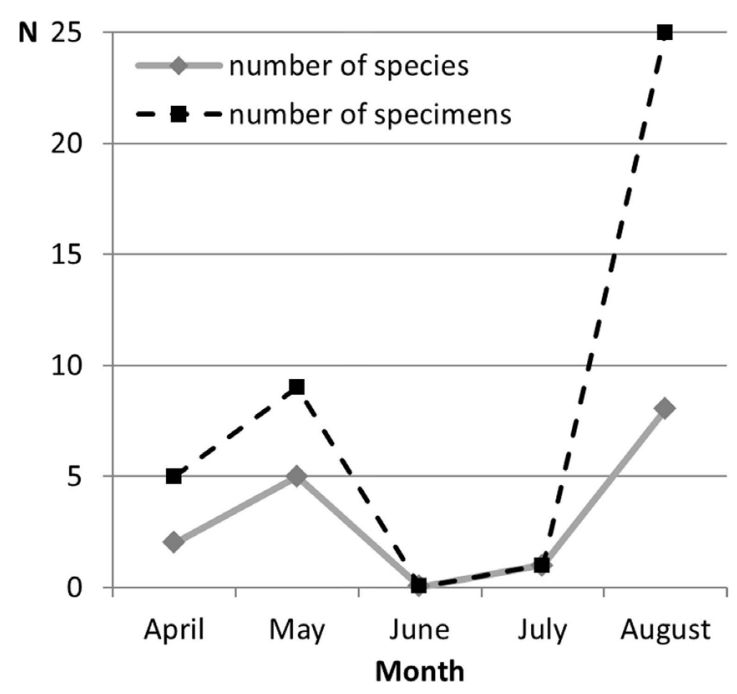

Fig. 4. Changes in the number of dragonfly species observed and the number of specimens collected after dredging (data collected from the dredged sites).

the control site, the numbers of specimens changed in accordance with the overall trend (Fig. 4). The differences between months obtained here were statistically insignificant (number of species: $H(3, N=17)=3.207, p=0.360$; number of larvae: $H(3, N=17)=1.367, p=0.713)$. It is worth noting that, in the period after the dredging, Gomphus vulgatissimus was caught earliest and in the greatest numbers at sites D1 and D2 (as early as April). This tendency was not observed in the 
P. Buczyński et al. : Knowl. Manag. Aquat. Ecosyst. 2016, 417, 43

Table 6. Correlations between the numbers of larvae in each species and environmental parameters.

\begin{tabular}{|c|c|c|c|c|c|c|}
\hline Species & Flow & Dredging & Sand & Silt & Detritus & Plants \\
\hline Calopteryx splendens & -0.193 & -0.007 & -0.166 & -0.029 & 0.195 & 0.013 \\
\hline Calopteryx virgo & -0.031 & -0.082 & 0.103 & -0.162 & -0.050 & 0.215 \\
\hline Platycnemis pennipes & -0.226 & -0.222 & -0.003 & -0.037 & 0.052 & 0.286 \\
\hline Ischnura elegans & -0.262 & -0.225 & -0.002 & -0.016 & 0.046 & 0.323 \\
\hline Erythromma najas & 0.020 & -0.051 & 0.130 & 0.182 & -0.183 & 0.017 \\
\hline Aeshna cyanea & -0.201 & -0.051 & 0.058 & 0.040 & -0.046 & 0.188 \\
\hline Aeshna mixta & -0.125 & -0.162 & -0.126 & -0.146 & 0.187 & 0.188 \\
\hline Gomphus vulgatissimus & 0.242 & 0.184 & 0.306 & -0.102 & -0.267 & -0.271 \\
\hline Somatochlora metallica & -0.201 & -0.051 & -0.126 & -0.146 & 0.187 & 0.188 \\
\hline Sympetrum vulgatum & -0.125 & 0.017 & 0.058 & 0.040 & -0.046 & 0.188 \\
\hline Total & -0.229 & -0.086 & 0.078 & -0.129 & 0.010 & 0.239 \\
\hline
\end{tabular}

rheobionts and rheophiles or in the eurytopes. At site D4, a single larva was caught, only in August.

The number of species caught as larvae at each site ranged from 1 to 4 , and their abundances ranged from 1 to 12 individuals. The differences between sites in the number of species, the number of larvae, and the Shannon-Wiener and Hurlbert indices were statistically insignificant; the results for the Kruskal-Wallis test were $H(12, N=29)=13.513, p=0.332 ; H$ $(12, \quad N=29)=12.112, \quad p=0.436 ; \quad H(12, \quad N=22)=14.727$, $p=0.256 ;$ and $H(12, N=22)=13.400, p=0.340$.

Statistically significant correlations were found between the abundances of some species of larvae and certain habitat factors. For example, the abundances of Platycnemis pennipes and Ischnura elegans were positively correlated with the degree of overgrowth. The abundance of Gomphus vulgatissimus was positively correlated with sand content and negatively correlated with detritus and the degree of bottom macrophyte overgrowth (Tab. 6).

A DCA was performed on the dragonfly species represented by larvae in the river before the dredging. The results showed that the length of the gradient represented by the first ordination axis was 5.145, which indicated that the species covered a full Gaussian spectrum. This coverage made it possible to conduct a direct ordination analysis of the CCA type to determine the relationships between the occurrence of species and the environmental parameters.

The results of the CCA for the samples collected from the River Krapiel before dredging showed that the variables used in the ordination could explain $50.5 \%$ of the total species variation in dragonfly larvae. The results of a stepwise selection of environmental variables showed that, among the variables considered, only the degree of bottom macrophyte overgrowth could significantly explain $(p \leq 0.05)$ the range of variation in the occurrence of species; this environmental factor was responsible for $9.7 \%$ of the species variation. Hence, species situated near the axis represented by this factor were well defined, and the remaining species were poorly defined by axes of other individual variables (Fig. 5). In samples collected before the dredging, we found that Calopteryx splendens and Platycnemis pennipes were clearly positively related to macrophytes. We found another detectable relationship between Gomphus vulgatissimus and a water current environment that favoured a sandy or silt bottom and

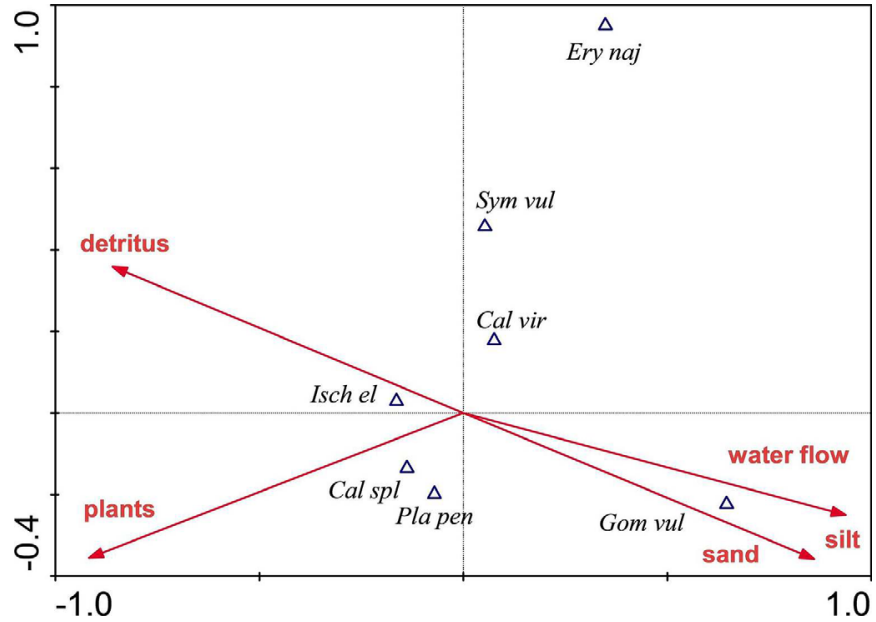

Fig. 5. CCA shows the effects of environmental parameters on the occurrence of dragonfly larvae before the dredging. Abbreviations: $\mathrm{Cal} \mathrm{spl}$ - Calopteryx splendens, Cal vir - Calopteryx virgo, Ery naj - Erythromma najas, Gom vul - Gomphus vulgatissimus, Pla pen Platycnemis pennipes, Sym vul - Sympetrum vulgatum.

avoided a bottom rich in detritus. However, the converse relationship held for Ischnura elegans.

Another DCA was performed on the dragonfly species represented by larval stages in the river after dredging. The results showed that the length of the gradient represented by the first ordination axis was $<0.001$, which only allowed the use of RDA ordination.

The results of a direct RDA for the samples collected from the Krapiel after dredging showed that the variables used in the ordination could explain $25.9 \%$ of the total dragonfly species variation. The results of a stepwise selection of environmental variables showed that, among these parameters, the degree of bottom macrophyte overgrowth could explain $2.6 \%$, the effect of dredging (measured as the negative passage of time since the dredging) could explain $2.0 \%$, and the water current could explain $1.1 \%$ of the variation in the occurrence of dragonfly species (Fig. 6). The sites with the greatest numbers of species after the dredging were characterized by a positive relationship between the species and habitats overgrown with macrophytes and silty bottoms (Erythromma najas, Sympetrum vulgatum, 


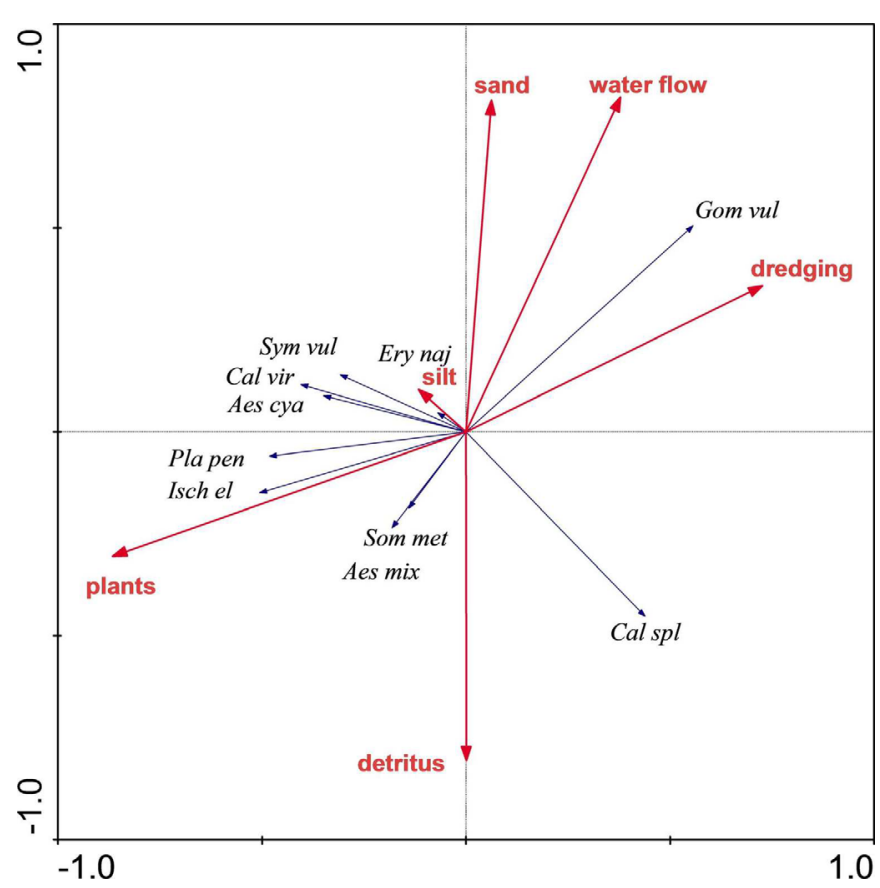

Fig. 6. RDA analysis shows the effects of environmental parameters on the occurrence of dragonfly larvae after the dredging. Abbreviations: Aes cya - Aeshna cyanea, Aes mix - Aeshna mixta, Cal spl Calopteryx splendens, Cal vir - Calopteryx virgo, Ery naj Erythromma najas, Isc ele - Ischnura elegans, Gom vul - Gomphus vulgatissimus, Pla pen - Platycnemis pennipes, Sym vul Sympetrum vulgatum.

Calopteryx virgo, Aeshna cyanea, Platycnemis pennipes and Ischnura elegans) or habitats covered with detritus (Aeshna mixta and Somatochlora metallica). Calopteryx splendens avoided a silty bottom, and Gomphus vulgatissimus preferred environments with water currents. The amount of time passed since the dredging was positively correlated with the abundance of G. vulgatissimus and negatively correlated with the abundance of Platycnemis pennipes, Ischnura elegans, Aeshna mixta, and Somatochlora metallica.

\section{Discussion}

The dragonfly assemblages of the Krapiel before dredging were qualitatively poor and harboured, at least in terms of larvae assemblages, a mixture of rheophilic and eurytopic species. Their composition was similar to that found in small natural watercourses in north-western Poland (Tończyk and Pakulnicka, 2006; Buczyński and Tończyk, 2013). However, it was equally similar, if not more similar, to the assemblages found in ditches and small canals. These habitats harbour a considerable proportion of eurytopic species, and among running water specialists, the dominance of a species lacks strict requirements (Buczyński, 2015). For at least 78 years, the analysed stretch of the Krapiel has flowed in an artificial channel, and it has almost certainly been dredged before; therefore, the dredging effects analysed in the present study may reflect part of a cyclical phenomenon. In this case, before the dredging, the assemblage would have been typical of a channel covered with mud and vegetation; from a hydro- technical perspective, that habitat would have benefited from an improvement in patency.

Our data confirmed the strong effect of dredging on dragonfly assemblages; however, only some of the indicators of change were statistically significant. After dredging, the initial effects were clearly driven by the mechanical removal of vegetation and sediments from the river, together with the dragonfly larvae inhabiting them. This removal destroyed the fauna completely, or at least to a great extent, and caused significant disturbances. Regeneration of dragonfly assemblages took place in altered habitat conditions, which was reflected in the altered dominance structure, particularly for larval assemblages. Data on imagos are, by nature, less reliable, particularly in the immediate vicinity of fish ponds. Adult dragonflies are good flyers (Corbet, 1999; Borisov, 2009); thus, outside the reproductive period, they disperse throughout the area and might fly great distances from their original water bodies. Moreover, the survival strategies of many species include attempts to colonize all available habitats, including some that may not be optimal (Corbet, 1999); this strategy often leads to failure in reproduction. For example, in the species Sympetrum depressiusculum, which is dominant in the fish ponds in Dzwonowo, over one-third of the population was found to have ranged over distances more than $0.5 \mathrm{~km}$ from their native water body (Dolný et al., 2014). In the present study, the distance between the Krapiel and neighbouring fish ponds was $15-20 \mathrm{~m}$, which was within the lower range of dispersal of adult Zygoptera, even during the reproductive period (Conrad et al., 2002).

Comparison of data from before and after the dredging showed different trends in the abundances of species associated with different microhabitats. In general, most phytophilic dragonflies reacted to dredging with negative (usually larvae) or stagnated abundance (usually imagos). This included the phytorheophiles, Calopteryx splendens and Platycnemis pennipes (Buczyński and Tończyk, 1997; Hoffmann and Mason, 2005; Rüppell et al., 2005). Removing the vegetation deprived these species of environments that played key roles in their life cycles. For example, it removed places where adults could be active, reproductive behaviour could take place, and larvae could live (Buchwald, 1989, 1992; Sternberg and Buchwald, 1999; Corbet, 2006). There were, however, some exceptions to this rule; e.g., Calopteryx virgo increased in abundance, and Pyrrhosoma nymphula appeared, when it was previously absent. These dragonflies prefer cool water with a rapid flow and/or water rich in oxygen (Rüppell et al., 2005; Bernard et al., 2009; Outomuro et al., 2010; Verberk and Calosi, 2012). These findings suggested that changes in the abundance of phytorheophiles were also influenced by changes in the hydrological conditions and associated changes in the physico-chemical characteristics of the water.

Rheophiles associated with the river bottom (Buczyński and Tończyk, 1997) were generally poorly represented. Larvae of Somatochlora metallica, a species that prefers a muddy bottom or a bottom with detritus (Wildermuth, 2008), were found only after the dredging. However, their low abundances made it difficult to rule out the possibility that this species was present, but undetectable, in the earlier period, particularly because the habitat changes associated with dredging were unfavourable to survival. In contrast, the RDA results indicated that the dredging benefited Gomphus vulgatissimus, 
which is better adapted to conditions associated with a rapid current and a bottom of fine sand (Müller, 1995).

After the dredging, more eurytopic species were noted, but their quantitative proportion in the larval assemblages was reduced by $10 \%$. Additionally, a decrease in the abundance of phytophiles was detected, particularly Ischnura elegans (Sternberg and Buchwald, 1999).

The time course of changes in the abundances of dragonfly larvae after the dredging and the possible genesis of these larvae were interesting. The original fauna was destroyed during the dredging; therefore, the question arose: where did the larvae that were caught come from? One possibility was that they were brought in with water from the fish ponds, which is a common route for fauna that live in connecting bodies of water (Buczyński, 2015). We could rule out this possibility, because the ponds were drained in the autumn, and the dredging, which was carried out in winter, eliminated any prior effects of this process. Moreover, the larvae observed in the spring could not have hatched from eggs laid after the dredging. In Polish climatic conditions, these species do not metamorphose until the end of April or beginning of May (Wendzonka, 2005). Therefore, if we take into account the time required for embryonic development and larval growth (Corbet, 1999; Sternberg and Buchwald, 1999, 2000), autogenic larvae would not be observed until summer. Accordingly, in August, a strong increase in dragonfly abundance was observed. On the other hand, the presence of larvae in the spring, though not particularly high in number, could most likely be explained by drift from the upper course of the river. Drift is usually greatest when large masses of water are present, which is typical in spring (or at least more common than in summer) (Brittain and Eikeland, 1988; Principe and del Carmen Corigliano, 2006; Baryshev and Veselov, 2007). The dependence of drift on changes in water flow was also demonstrated previously, in analyses of drift in anthropogenic conditions (Castro et al., 2013).

In the growing season, colonization by adult dragonflies became significant. They arrived both from nearby water bodies and from sites along the same watercourse. Dragonflies are known for their rapid, often nearly instantaneous colonization and recolonization of habitats (e.g., Chovanec and Raab, 1997; Buczyński, 1999; Hubble and Hurst, 2003; Kadoya et al., 2004; Pickess, 2004; Buczyński, 2015), but this mainly applies to eurytopic and pioneer species. However, species like those in the Calopteryx genus are known to travel along a watercourse. Although only a small proportion of the population (up to $5 \%$ ) might migrate long distances, those individuals can travel up to $4 \mathrm{~km}$ in one day (Stettmer, 1996). Thus, a dredged segment of a river, particularly a relatively short stretch, can be very quickly colonized by imagos. When they find suitable conditions for development and reproduction, the odonatocoenosis can be restored fairly quickly, though the form of the assemblage will be at least partly different from the original assemblage. In the case of the Krąpiel, even in the early stages of recolonization, there was a shift towards an assemblage with strong stream characteristics.

In terms of environmental protection, dredging a river with a natural habitat system can only be regarded as destruction. However, how should we regard the same procedure performed in a river which was previously regulated, or which undergoes cyclical regulation and represents a severely impoverished habitat? Our data confirmed the hypotheses proposed in some studies (cited in the Introduction: Holčík and Macura, 2001; Poff and Zimmerman, 2010), which suggested that an assessment may not always show negative effects. The dredging of the Krapiel did not permanently alter the state of the river fauna; after a temporary deterioration, the fauna rapidly began to regenerate, and it moved in the direction of a more natural assemblage, rich in the stenotopes typical of this environment. Similar results were observed in this same river for ostracods, water mites, beetles, caddisflies, true bugs, and molluscs (Szlauer-Łukaszewska and Zawal, 2014; Zawal et al., 2015, 2016a,b; Dąbkowski et al., 2016; Płaska et al., 2016). From this perspective, dredging some regulated rivers can sometimes be beneficial, and it can be repeated, provided the impact is monitored. Although dredging is typically carried out for economic reasons, at least some of its effects could be similar to re-naturalization. It should not, however, be carried out on long stretches of the river at once, because it is important to retain refuges of fauna that can recolonize the dredged stretches. In this context, it is worth considering the utility of the "rotation model", which would employ periodic dredging of short stretches of river, at alternate sites, separated by suitably long periods of time. This approach would be conducive to high species diversity, because it preserves a mosaic of many different stages of succession. Rotationdredging procedures have been successfully introduced to protect dragonflies in peat bog pools and ditches (Wildermuth, 2001; Buczyński, 2015). These procedures are even more necessary in small watercourses of natural origin, which are so often transformed and degraded (Lüderitz et al., 2004; Stryjecki, 2013).

\section{Conclusions}

This study illustrated the influence of dredging on the dragonfly assemblages of the small, regulated lowland River Krapiel and concluded the following:

- by monitoring odonate assemblages in a small lowland river after dredging, we showed that dragonfly assemblages had recovered within six months after the intervention;

- the recolonization of dragonflies first occurred as a result of larval drift, and then, via dispersion of imagos;

- different physico-chemical parameters and microhabitat availabilities influenced the species composition of Odonata assemblages before and after dredging;

- compared to assemblages observed before the intervention, the emerging assemblages were more typical of those found in small, natural running waters;

- in general, dredging could be assessed as a phenomenon that unintentionally had a positive influence on species composition of dragonfly assemblages; under controlled conditions, it might even contribute to the protection of natural river fauna.

Acknowledgment. Financial support was provided by the Ministry of Science and Higher Education of Poland, Grant No. N305 222537.

\section{References}

Aldridge DC. 2000. The impacts of dredging and weed cutting on a population of freshwater mussels (Bivalvia: Unionidae). Biol Conserv 95: 247-257. 
Baryshev LA, Veselov AE. 2007. Seasonal dynamics of benthos and invertebrate drift in some tributaries on Onega Lake. Biol Inland Waters 1: 74-80.

Benke AC, Wallace JB, Harrison JW, Koebel JW. 2001. Food web quantification using secondary production analysis: predaceous invertebrates of the snag habitat in a subtropical river. Freshw Biol 46: 329-346.

Bernard R, Buczyński P, Tończyk G, Wendzonka J. 2009. A distribution atlas of dragonflies (Odonata) in Poland. Poznań: Bogucki Wydawnictwo Naukowe, $256 \mathrm{p}$.

Borisov SN. 2009. Study of dragonfly (Odonata) migrations in the Western Tien Shan mountains using ornithological traps. Entomol Rev 89: 1025-1029.

Braun-Blanquet J. 1964. Pflanzensociologie: Grundzüge der Vegetationskunde. 3te Aufl. Wienn: Springer-Verlag, 865 p.

Brittain JE, Eikeland TJ. 1988. Invertebrate drift - a review. Hydrobiologia 166: 77-93.

Buchwald R. 1989. Die Bedeutung der Vegetation für die Habitatsbindung einiger Libellenarten der Quellmoore und Fließgewässer. Phytocoenologia 17: 307-448.

Buchwald R. 1992. Vegetation and dragonfly fauna - characteristics and examples of biocenological field studies. Vegetatio 101: 99-107.

Buczyński P. 1999. Dragonflies (Odonata) of sand pits in southeastern Poland. Acta Hydrobiol 41: 219-230.

Buczyński P. 2015. Dragonflies (Odonata) of anthropogenic waters in middle-eastern Poland. Olsztyn: Wydawnictwo Mantis, 272 p.

Buczyński P, Tończyk G. 1997. Analysis of dragonfly assemblages (Odonata) in running waters in Poland. In: Burchard L, Messyasz B, eds. XVII Zjazd Hydrobiologów Polskich. Poznań, 8-11 września 1997. Sorus, Poznań: Materiały zjazdowe, p. 95 (in Polish).

Buczyński P, Tończyk G. 2013. Dragonflies (Odonata) of Tuchola Forests (northern Poland). 1. Wdzydzki Landscape Park. Ann Univ M Curie-Sktodowska (C) 68: 75-103.

Bulánková E. 1997. Dragonflies (Odonata) as bioindicators of environment quality. Biologia 52: 177-180.

Carpenter SR, Stanley EH, Vander Zanden MJ. 2011. State of the World's freshwater ecosystems: physical, chemical, and biological changes. Ann Rev Environ Resour 36: 75-99.

Castro DMP, Hughes RM, Callisto M. 2013. Influence of peak flow changes on the macroinvertebrate drift downstream of a Brazilian hydroelectric dam. Braz J Biol 73: 775-782.

Chovanec A, Raab R. 1997. Dragonflies (Insecta, Odonata) and the ecological status of newly created wetlands - examples for longterm bioindication programmes. Limnologica 37: 381-392.

Chovanec A, Waringer J. 2001. Ecological integrity of riverfloodplain systems - assessment by dragonfly surveys. Regul Rivers Res Manage 17: 493-507.

Chovanec A, Waringer J, Raab R, Laister G. 2004. Lateral connectivity of a fragmented large river system: assessment on a macroscale by dragonfly surveys (Insecta: Odonata). Aquat Conserv Mar Freshw Ecosyst 14: 163-178.

Conrad KF, Wilson KH, Whitefield K, Harvey IF, Thomas CJ, Sheratt TN. 2002. Characteristics of dispersing Ischnura elegans and Coenagrion puella (Odonata): age, size, morph and ectoparasitism. Ecography 25: 439-445.

Corbet PS. 1999. Dragonflies. Behaviour and ecology of Odonata. Colchester: Harley Books, Colchester, 829 p.

Corbet PS. 2006. Forest as habitats for dragonflies (Odonata). In: Cordero Rivera A, ed. Forest and dragonflies. Fourth WDA International Symposium of Odonatology, Pontevedra (Spain), July 2005, Pensoft, Sofia - Moscow, pp. 13-36.
Czachorowski S, Lewandowski K, Wasilewska A. 1993. The importance of aquatic insects for the landscape integration in the catchment area of the River Gizela (Masurian Lake District, northeastern Poland). Acta Hydrobiol 35: 49-64.

da Silva Monteiro Júnior C, Juen L, Hamada N. 2015. Analysis of urban impacts on aquatic habitats in the central Amazon basin: adult odonates as bioindicators of environmental quality. Ecol Indic 48: 303-311.

Dąbkowski P, Buczyński P, Zawal A, et al. 2016. The impact of dredging of a small lowland river on aquatic beetle fauna (Coleoptera). J Limnol 75: 472-487.

de Jonge VN, de Jong DJ. 2002. Ecological restoration in coastal areas in the Netherlands: concepts, dilemmas and some examples. Hydrobiologia 478: 7-28.

Dolný A, Harabiš F, Mižičová H. 2014. Home range, movement, and distribution patterns of the threatened dragonfly Sympetrum depressiusculum (Odonata: Libellulidae): a thousand times greater territory to protect? PLOS ONE 9: e100408.

Gerlach J, Samways MJ, Pryke J. 2013. Terrestrial invertebrates as bioindicators: an overview of available taxonomic groups. $J$ Ins Conserv 17: 831-850.

Hill MO, Gauch HG. 1980. Detrended correspondence analysis: an improved ordination technique. Vegetatio 42: 47-58.

Hoffmann TA, Mason CF. 2005. Habitat characteristics and the distribution of Odonata in a lowland river catchment in eastern England. Hydrobiologia 539: 137-147.

Holčík J, Macura V. 2001. Some problems with the interpretation of the impact of stream regulations upon the fish communities. Ekológia 20: 423-434.

Hubble DS, Hurst D. 2003. Management of small dug ponds for Odonata conservation and colonization in an area of valley mire and wet heathland (Bourne Valley, Dorset). J Br Dragonfly Soc 19: 24-34.

Kadoya T, Suda S, Washitani I. 2004. Dragonfly species richness on man-made ponds: effects of pond size and pond age on newly established assemblages. Ecol Res 19: 461-467.

Kamada M, Woo H, Takemon Y. 2004. Ecological engineering for restoring river ecosystems in Japan and Korea. In: Hong S-K, Lee JA, Ihm B-S, Farina A, Son Y, Eun-Shik K, Choe JC, eds. Ecological Issues in a Changing World. Dordrecht: Kluwer, pp. 337-353.

Kiene S. 1996. Synthese von biologischer und wasserbaulicher Analyse zur Bewertung von renaturierten Fließgewässern der Oberrheinebene. Karlsruhe: Institut für Wasserbau und Kulturtechnik, $258 \mathrm{p}$.

Kondracki J. 2000. Regional geography of Poland. Warszawa: Wydawnictwo Naukowe PWN, 440 p. (in Polish).

Koprowska L, Jabłońska-Barna I. 2007. Biomonitoring of the Łyna River (North Poland) in the years 1974-2006 on the basis of the benthic macroinvertebrates. Oceanol Hydrobiol St 36 (Suppl. 4): $49-54$.

Lampert W, Sommer U. 1997. Limnoecology: The Ecology of Lakes and Streams. Oxford: Oxford University Press, 382 p.

Lüderitz V, Jüpner R, Müller S, Feld CK. 2004. Renaturalisation of streams and rivers - the special importance of integrated ecological methods in measurement of success. An example of Saxony Anhalt (Germany). Limnologica 34: 249-263.

Motta RL, Uieda VS. 2004. Diet and trophic groups of an aquatic insect community in a tropical stream. Braz J Biol 64: 809-817 (in Portuguese).

Müller O. 1995. Ökologische Untersuchungen an Gomphiden (Odonata: Gomphidae) unter besonderer Berücksichtigung ihrer Larvenstadien. Göttingen: Cuvillier Verlag, 234 p. 
Naiman RJ, Magnuson JJ, McKnight DM, Stanford JA, Karr JR. 1995. Freshwater ecosystems and management: a national initiative. Science 270: 584-585.

Outomuro D, Torralba-Burrial A, Ocharan FJ. 2010. Distribution of the Iberian Calopteryx damselflies and its relation with bioclimatic belts: evolutionary and biogeographic implications. J Ins Sci 10: 6 .

Phelps HL. 2001. Biomonitoring Anacostia River Estuary pollutants with the Asiatic clam (Corbicula fluminea): possible effects of dredging. Final Technical Report. Washington, DC: DC Water Resources Research Center, 17 p.

Pickess BP. 2004. Rapid colonisation of a newly dug pond on a Polish heathland. J Br Dragonfly Soc 20: 4.

Płaska W, Zawal A, Kurzątkowska A, Stępień E, SzlauerŁukaszewska A. 2016. The effect of dredging of a small lowland river (Krapiel - NW Poland) on aquatic Heteroptera. Ann Zool Fenn 53: 139-153.

Poff NL, Zimmerman JKH. 2010. Ecological responses to altered flow regimes: a literature review to inform the science and management of environmental flows. Freshw Biol 55: 194-205.

Poff NL, Olden JD, Vieira NKM, Finn DS, Simmons MP, Kondratieff BC. 2006. Functional trait niches of North American lotic insects: traits-based ecological applications in light of phylogenetic relationships. J N Am Benthol Soc 25: 730-755.

Principe RE, del Carmen Corigliano M. 2006. Benthos, drifting and marginal macroinvertebrate assemblages in a lowland river: temporal and spatial variations and size structure. Hydrobiologia 553: 303-317.

Rosenberg DM, McCully P, Pringle CM. 2000. Global-scale environmental effects of hydrological alterations: Introduction. BioSci 50: 746-751.

Rüppell G, Hilfert-Rüppell D, Rehfeldt G, Schütte C. 2005. Prachtlibellen Europas. Hohenwarsleben: Westarp Wissenschaften, $255 \mathrm{p}$.

Sahlén G, Ekestubbe K. 2001. Identification of dragonflies (Odonata) as bioindicators of general species richness in boreal forest lakes. Biodiv Conserv 10: 673-690.

Smith EP, Orvos DR, Cairns Jr J. 1993. Impact assessment using the before-after-control-impact (BACI) model: concerns and comments. Can J Fish Aquat Sci 50: 627-637.

Sternberg K, Buchwald R, eds. 1999. Die Libellen BadenWürttembergs. Band 1. Allgemeiner Teil, Zygoptera. Stuttgart (Hohenheim): Eugen Ulmer, 468 p.

Sternberg K, Buchwald R, eds. 2000. Die Libellen BadenWürttembergs. Band 2. Großlibellen (Anisoptera), Literatur. Stuttgart (Hohenheim): Eugen Ulmer, 712 p.

Stettmer C. 1996. Colonisation and dispersal patterns of banded (Calopteryx splendens) and beautiful demoiselles (C. virgo) (Odonata: Calopterygidae) in south east German streams. Eur $J$ Ent 93: 579-593.
Stryjecki R. 2013. A faunistic and ecological characterization of the water mites (Acari: Hydrachnidia) of the highly anthropologically transformed Mietiułka river in Polesie National Park. Ochr S rodow Zas Nat 24: 11-15.

Svendsen KM, Renshaw CE, Magilligan FJ, Nislow KH, Kaste JM. 2009. Flow and sediment regimes at tributary junctions on a regulated river: impact on sediment residence time and benthic macroinvertebrate communities. Hydrol Process 23: 284-296.

Szlauer-Łukaszewska A, Zawal A. 2014. The impact of river dredging on ostracod assemblages in the Krapiel River (NW Poland). Fundam Appl Limnol 185: 295-305.

ter Braak CJF. 1986. Canonical correspondence analysis: a new eigenvector technique for multivariate direct gradient analysis. Ecology 67: 1167-1179.

ter Braak CJF, Prentice IC. 1988. A theory of gradient analysis. Adv Ecol Res 18: 271-371.

ter Braak CJF, Verdonschot PFM. 1995. Canonical correspondence analysis and related multivariate methods in aquatic ecology. Aquat Sci 57: 255-289.

Tończyk G, Pakulnicka J. 2006. Dragonflies (Odonata) of "Tucholskie Forests" National Park - analysis of data from the year 2004. In: Banaszak J, Tobolski K, eds. Park Narodowy Bory Tucholskie. U progu nowej dekady. Wydawnictwo Uniwersytetu im. Bydgoszcz: Kazimierza Wielkiego w Bydgoszczy, pp. 209-221 (in Polish)

Verberk WCEP, Calosi P. 2012. Oxygen limits heat tolerance and drives heat hardening in the aquatic nymphs of the gill breathing damselfly Calopteryx virgo (Linnaeus, 1758). J Therm Biol 37: 224-229.

Ward JV, Tockner K, Schiemer F. 1999. Biodiversity of floodplain ecosystems: ecotones and connectivity. Regul Rivers Res Manage 15: $125-139$.

Wendzonka J. 2005. Identification key to the imagines of Polish dragonflies (Odonata). Odonatrix 1 (Suppl. 1): 1-26 (in Polish).

Wildermuth H. 2001. Das Rotationsmodell zur Pflege kleiner Moorgewässer - Simulation naturgemässer Dynamik. Nat Schutz Landsch Plan 33: 269-273.

Wildermuth H. 2008. Die Falkenlibellen Europas. Corduliidae. Hohenwarsleben: Westarp Wissenschaften, 497 p.

Zawal A, Stępień E, Szlauer-Łukaszewska A, et al. 2015. The influence of a lowland river dredging (the Krapiel in NW Poland) on water mite fauna (Acari: Hydrachnidia). Fundam Appl Limnol 186: 217-232.

Zawal A, Czachorowski S, Stępień E, et al. 2016a. Early postdredging recolonization of caddisflies (Insecta: Trichoptera) in a small lowland river (NW Poland). Limnology 17: 71-85.

Zawal A, Sulikowska-Drozd A, Stępień E, Szlauer-Łukaszewska A, Jankowiak Ł. 2016b. Regeneration of the molluscan fauna of a small lowland river after dredging. Fundam Appl Limnol 187: 281-293.

Cite this article as: Buczyński P, Zawal A, Buczyńska E, Stępień E, Dąbkowski P, Michoński G, Szlauer-Łukaszewska A, Pakulnicka J, Stryjecki R, Czachorowski S. 2016. Early recolonization of a dredged lowland river by dragonflies (Insecta: Odonata). Knowl. Manag. Aquat. Ecosyst., 417, 43. 